\title{
Peers as Agents of Dating Violence Prevention: Feasibility Analysis of an Intervention
}

\begin{abstract}
Karine Brito dos Santos ${ }^{1}$
Orcid.org/0000-0002-9185-1999

Sheila Giardini Murta*, 2

Orcid.org/0000-0001-5515-5219

${ }^{1}$ Universidade Federal da Integração Latino-Americana - UNILA, Foz do Iguaçu, PR, Brasil

${ }^{2}$ Universidade de Brasília, Brasília, DF, Brasil

Abstract

The present study examined feasibility evidence of a peer-based intervention in preventing dating violence by monitoring process indicators during the implementation phase of pilot studies. Two pilot studies were carried out in cities from different Brazilian regions with the participation of 25 high schoolers. Quantitative and qualitative measurements were used and this data was explored, respectively, by frequency count and content analysis. The study identified, on the one hand, evidence supporting the intervention, with good indicators of satisfaction and participant involvement, but on the other hand, contextual barriers that hampered recruitment, restricted the reach of the intervention, prevented the delivery of the number of planned sessions, and created roadblocks to the participants' adherence. In spite of such barriers, monitored process indicators testify in favor of the acceptability of the intervention if integrated into the school curriculum and changed its format to make it shorter.
\end{abstract}

Keywords: Prevention, dating violence, feasibility study, peer education.

\section{Pares como Agentes de Prevenção à Violência no Namoro: Análise da Viabilidade de uma Intervenção}

\section{Resumo}

O presente estudo examinou evidências de viabilidade de uma intervenção baseada nos pares para prevenção à violência no namoro, monitorando indicadores de processo durante a fase de implementação de estudos piloto. Foram realizados dois estudos pilotos em cidades de regiões distintas do Brasil, com a participação de vinte e cinco adolescentes do ensino médio. Foram usadas medidas quantitativas e qualitativas, cujos dados foram explorados, respectivamente, pela contagem de frequência e análise de conteúdo. O estudo identificou por um lado, evidências favoráveis à aceitabilidade da intervenção, com bons indicadores de satisfação e envolvimento dos participantes e, por outro, barreiras contextuais

* Mailing address: Universidade de Brasília, Instituto de Psicologia, Departamento de Psicologia Clínica, Campus Darcy Ribeiro, Brasília - DF, Brazil 70.910-900. Phone: 6199633 9631. E-mail: giardini@unb.br and karine.unb@gmail.com

Support: Coordination for the Improvement of Higher Education Personnel (CAPES). 
que dificultaram o recrutamento, restringiram o alcance da intervenção, impediram a oferta do número de sessões planejadas e geraram impasses à adesão dos participantes. Em que pese tais barreiras, os indicadores de processo monitorados depõem a favor da aceitabilidade da intervenção, se integrada ao currículo escolar e alterado o seu formato no sentido de torná-la mais breve.

Palavras-chave: Prevenção, violência no namoro, estudo de viabilidade, educação de pares.

\section{Pares como Agentes de Prevención à la Violencia en el Noviazgo: Análisis de Viabilidad de una Intervención}

\section{Resumen}

El presente estudio examinó evidencias de viabilidad de una intervención basada en los pares para prevenir la violencia en el noviazgo, monitoreando indicadores de proceso durante la fase de implementación de estudios piloto. Se realizaron dos estudios pilotos en ciudades de regiones distintas de Brasil, con la participación de veinticinco adolescentes de la enseñanza media. Se utilizaron medidas cuantitativas y cualitativas, cuyos datos se explotaron, respectivamente, por el recuento de frecuencia y el análisis de contenido. El estudio identificó, por un lado, evidencias favorables a la aceptabilidad de la intervención, con buenos indicadores de satisfacción y participación de los participantes y, por otro, barreras contextuales que dificultaron el reclutamiento, restringieron el alcance de la intervención, impidieron la oferta del número de sesiones planificadas y generaron impasses a la adhesión de los participantes. En que pese a tales barreras, los indicadores de proceso monitoreados deponen a favor de la aceptabilidad de la intervención, si se integra al currículo escolar y cambian su formato para hacerla más breve.

Palabras clave: Prevención, violencia en el noviazgo, estudio de viabilidad, educación de pares.

Violence between intimate partners in premarital relationships, known as dating violence, is a serious public health problem and a potential precursor of domestic violence in adult life (Smith, Ireland, Park, Elwyn, \& Thornberry, 2011). Over the last decade several programs have been implemented, particularly in the United States and Europe (Edwards \& Hinsz, 2014; Leen et al., 2013), with a clear guideline in the area: preventing dating violence is a key strategy in the primary prevention of adult intimate partner violence (Foshee, Reyes, \& Ennett, 2010). With a substantial increase in research in this field in the last few years and results sometimes presenting positive effects of the interventions that dissipate over time and sometimes significant benefits in the long term (Leen et al., 2013), it is important to broaden the design, monitoring, and evaluation methods of the interventions (Shorey et al., 2012).

In Brazil, as in the findings of international studies (Paradis, Hébert, \& Fernet, 2017), 83.9\% of cases of physical and psychological violence are perpetrated by both partners, pointing to a bidirectional pattern of aggression in adolescent intimate relationships (Barreira, Lima, Bigras, Njaine, \& Assis, 2014). Despite that, initiatives to prevent youth dating violence are still rare in Brazil (Murta et al., 2016; Murta et al., 2013; Priolo, 2017). Interventions to reduce dating violence that assist in the early identification of the problem are fundamental, especially in light of its negative impact on the emotional, physical, and sexual health of the youths. In the face of the paucity of primary prevention technologies for dating violence in Brazil, the present study aims to contribute to the research in the area by documenting the implementation of pilot studies and examining the feasibility of a peerand bystander approach-based interventions for preventing adolescent dating violence.

Peer influence is relevant in the design of an intervention of this kind given that several relational factors in this domain can affect 
trajectories of victimization and/or perpetration and maximize the risk of dating violence, such as: knowing victims or perpetrators of dating violence in one's peer network (McDonell, Ott, \& Mitchell, 2010); having previous experience with violence between peers or dating violence (Boivin, Lavoie, Hébert, \& Gagné, 2012); high exposure to aggressive behavior models between peers (Foshee et al., 2012); and attitudes (Leen et al., 2013) and norms (Thompson, 2014) from the peers accepting such practices in affectivesexual relations. In the face of this, changing the peer response to dating violence (Foshee et al., 2005) has been a highly recommended preventive strategy (Weisz \& Black, 2010).

Peers are often among the primary witnesses of dating violence. Therefore, preparing them to offer qualified help may be the fundamental route to preventing dating violence in sexualaffective relationships. The bystander approach constitutes, as a matter of fact, a potentially powerful tool in the efforts to prevent dating violence (Storer, Casey, \& Herrenkohl, 2016). Interventions based on this approach shift the focus of attention from the potential victim and to the potential perpetrator to the peers and community members (Branch, Richards, \& Dretsch, 2013), given the principle that "all members of community have a role in changing social rules to prevent violence" (Coker et al., 2011, p. 779). Educating the youth about their role as bystanders is fundamental so that they, instead of behaving in passive and silent manner, have the engagement and self-efficacy to help in situations of dating violence among their peers.

The efficacy of interventions for preventing dating violence based on the bystander approach has been investigated in a few quasi-experimental (Amar, Tuccinardi, Heislein, \& Simpson, 2015) and experimental (Coker et al., 2011; Coker et al., 2015; Miller et al., 2012; Palm Reed, Hines, Armstrong, \& Cameron, 2014) studies performed in the Northern Hemisphere in schools and universities. The studies aimed to prepare the youths to recognize dating violence and to intervene, offering qualified help to their friends. These studies' findings suggested that interventions with this focus, in comparison to the control group, produce greater identification of violence (Miller et al., 2012), intention to help (Amar et al., 2015; Miller et al., 2012), perception of the responsibility to help, skills to offer help as bystanders (Amar et al., 2015), and helpful behaviors for bystanders (Coker et al., 2011; Miller et al., 2012). Moreover, the participants reported a decrease in norms of violence acceptance (Amar et al., 2015; Coker et al., 2011; Palm Reed et al., 2014) as well as violence victimization and perpetration (Coker et al., 2015).

In contrast, in Brazil although the education to support peers involved in sexualaffective relationships in a safe and effective way is a relevant necessity (Murta, Ramos, Tavares, Cangussú, \& Costa, 2014; Soares, Lopes, \& Njaine, 2013), peer- and bystander approach-based interventions for preventing dating violence, directed at adolescents and undertaken in the school environment, are, to our knowledge, nonexistent. Contextual differences may be substantial between the implementation environments of the studies above and Brazilian schools, the target of this study. Thus, the mode's intervention design for Brazilian schools' adolescents employs an innovative approach and, as such, feasibility analyses are recommended.

Feasibility studies are recommended in the developmental phase of interventions. This study's purpose is to answer the following questions: (1) Acceptability: is the intervention satisfactory and appropriate to those who received it and those who applied it?; (2) Demand: are the intervention's activities or components responsive to the target population's needs and used by them?; (3) Implementation: can the intervention can be fully implemented as planned, within the existing context, or are there other factors that facilitate or impede it? (4) Practicality: was it possible to implement the intervention with the given resources, means, and circumstances - that is, with the proper intensity, duration, and frequency? (5) Adaptation: are changes in content or in procedures appropriate for new situations to accommodate context elements and possible needs for modifications 
in the intervention format? (6) Integration: does the intervention's implementation in the existing infrastructure require organizational changes? (Bowen et al., 2009). Evaluating an intervention's potential efficacy can be an objective of viability studies as well. Besides determining if more tests are necessary for this intervention, such studies also supply evidence about whether the intervention is promising enough, and thus, if such effort is justified.

The association between intervention efficacy and implementation quality is widely documented. Evidence indicates that carefully implemented programs produce superior results compared to poorly implemented ones (Durlak \& DuPree, 2008; Moore et al., 2014). Therefore, adequately documenting the implementation process is a pressing need when the potential value of a new interventions is under study, as it is in pilot studies. Pilot studies aim to test the program as it would be implemented in practice, before the definitive implementation, seeking to provide useful data capable of determining if the program can be carried out, if its messages are understandable, if its content is appropriate, if the result of the planning is attractive, and above all, if the adopted procedures are viable and responsive to the target audience and context (Bartholomew, Parcel, Kok, Gottlieb, \& Fernandéz, 2011).

Pilot studies conducted during intervention development aim to monitor the implementation process, correct errors during it, and adapt the intervention to the target audience and context. Epidemiological, social, political, cultural, economic, legal, and ethical contexts possess aspects that can interact with the implementation agents and with the intervention itself as well as with its components and strategies to directly affect, positively or negatively, the implementation process, the results, and the implementation impact (Pfandenhauer et al., 2017). In this regard, pilot studies can be helpful in identifying an intervention's mechanisms of action and preventing iatrogenic effects and waste of resources (Bonell, Jamal, MelendezTorres, \& Cummins, 2015). As a consequence, the likelihood of adherence, retention, and efficacy in future implementations are increased. Feasibility studies with this purpose, directed at extracting lessons from the implementation process to improve the intervention, differ from the predominant production in the field, which is limited to evaluating the potential efficacy of interventions (Wuest et al., 2015).

That said, the present study seeks to amplify the production of knowledge of feasibility studies and thereby inform the intervention development process. The lessons learned in studies of this type can foster the efficient development of social technologies, optimizing the use of scarce resources, and producing an improved response to social problems with the least possible cost. These are, thus, desirable studies both ethically and technically. This study's objective was to evaluate the viability of a peer-based, bystander-based intervention for the prevention of dating violence between adolescents by monitoring process indicators during the implementation of two pilot studies. Specifically, the study aimed to examine to what extent the intervention in question was shown to be satisfactory from the participants' point of view (acceptability), usable by the participants and adjustable to the school culture (demand), executable in its implementation (implementation), practicable from the point of view of resources necessary for its execution (practicality), malleable to attend different contexts (adaptation), and amenable to being integrated into the infrastructure available in the school context (integration).

\section{Method}

\section{Design}

This was a feasibility study of an intervention (Bowen et al., 2009). Feasibility studies constitute the first step in the creation of evidencebased interventions and enable the identification of, among other things: (a) vital processes and content characteristics that promote its acceptability; (b) modifications needed to boost its appropriateness and, consequently, its responsivity (Wuest et al., 2015); (c) the appropriateness of the procedures used in the 
intervention; and (d) the impact of contextual factors of the implementation (Mohatt, Fok, Henry, People Awakening Team, \& Allen, 2014).

This viability study was conducted via two pilot studies in two public schools, the first in the city of Brasilia (in the Distrito Federal) and the second in the city of Foz do Iguaçu (in the state of Paraná). The results of the process evaluation of pilot study 1 (PS1) informed the completion of pilot study 2 (PS2). Two distinct contexts were selected for examining the viability of the intervention in the face of various opportunities and restrictions. The study was approved by the Committee for Ethics in Research of the Human Sciences Institute of the University of Brasilia under Report 411.000.

\section{Participants}

In PS1, 18 students from the $11^{\text {th }}$ grade of a public school in Brasilia participated: 13 girls and 5 boys between the ages of 16 and 19 . In the second pilot, 7 students, 5 girls (between 14 and 17) and 2 boys from the $10^{\text {th }}$ and $11^{\text {th }}$ grades, from a public school in the city of Foz do Iguaçu participated.

\section{Instruments}

The following instruments were used in the process evaluation of PS1 and PS2:

Field Diary: the facilitator recorded, after each session, the following free-form written records in the field diary: (1) intervention components delivered to the participants and the content addressed by session (dose delivered); (2) individual attendance of the participants for each session (reach); (3) modes of access to the participants and results obtained (recruitment); and (4) barriers to the intervention (context). These criteria were based on Steckler and Linnan (2002).

Dose Received Record (Murta et al., 2009): This was used to collect participants' reports about the daily application of the content taught in the intervention (received dose, as named by Steckler \& Linnan, 2002). The form is filled out by each participant individually by hand at the beginning of each session with what had been put into practice since the last session according to the prompt, in the "What have you put into practice this week from the intervention? Practicing is every little step: thinking, wishing, or acting .... Write here: ...".

Session Satisfaction Scale (Murta et al., 2016): This seeks to evaluate the participants' satisfaction with the intervention. It has eight faces that express emotions designated by the qualifiers: "Awesome", "Great", "Cool”, "Pretty good", "So-so", "Bad", "Awful”, and "Horrible”. Beyond individually indicating one's degree of satisfaction at the end of each session, the option to specify the reason for one's choice was provided to the participant via an open question.

Apart from the instruments used in the process evaluation, at the end of the intervention a qualitative evaluation of the following form was performed: in PS1, the participants catalogued in writing the strong and weak points of the intervention as well as commenting freely. In PS2, the participants responded to the question proposed by Murta et al. (2012): "What effects did this process have?", completing in writing the sentences "I feel that...", "I thought that ...", "I wanted to...", and "I gave myself the task of...".

\section{Procedures}

Recruitment. The two public high schools were selected by convenience. In Brasilia (PS1), the intervention was integrated into the school curriculum subject to the Interdisciplinary Project (PI), which includes various activities offered during school hours to the students, who are solely responsible for expressing their interest in participating. In order to adapt the PI proposal to the intervention, a workshop titled "Oficina nAMORo à primeira vista" ("beLOVEd at first sight Workshop”) was offered. In Foz do Iguaçu (PS2), in contrast with PS1, as it was not possible to implement the project during school hours, instead it took place outside of the normal school schedule. Twenty-five seats were available for the intervention. In PS2, it was decided to use the first session only for introducing the project and the second for gathering expectations, having in mind that in PS1, some students began in the 
second meeting after being invited by classmates who had come to the first.

In Brasilia, students were recruited to participate in the workshop through a poster hung on the school wall and a banner located on the school's Facebook page. In Foz do Iguaçu, students attended a talk titled "Romantic Relationships" advertised by posters on the school walls as well as through by a banner on the school's Facebook page. Additionally, after the talk in the classrooms, in-person awarenessraising inviting the students to participate in the project was done.

Data Collection. The intervention, called Peer Leader Training (PLT), was composed of 10 weekly group sessions with a duration of 90 minutes each. The intervention curriculum encompasses three thematic dimensions: dating violence (sessions 2, 5, and 6), peer influence (sessions 3 and 4), and the bystander approach (sessions 7, 8, and 9). The first dimension, romantic violence, comprises the themes of being in love; expressions of dating violence; romantic relationship quality; risk and protective factors; myths about dating violence; and the impact of dating violence on health. In the second dimension, peer influence, the structural qualitative characteristics of peer groups; changes in the peer network and in the nature of relationships with friends; the role of peers in development, maintenance, and protection in cases of dating violence; peer support in handling dating violence; and the role of peer leaders in the prevention of dating violence are included. The third dimension, the bystander approach, collects the roles of the aggressor, victim, and bystander; initiative vs. passiveness of the bystander; stages of and barriers to bystander intervention; safe and risky bystander interventions; direct and indirect bystander intervention strategies; selfefficacy; and conflict resolution, peer resistance, and help skills. Although dimension three was part of the intervention's curriculum as intended to be offered to participants, only the first two dimensions were implemented in this study due to the idiosyncrasies of the context, as will be seen below.
The intervention took into account psychoeducational and experiential activities such as warm-up activities, expository dialogs, relaxational activities, and group dynamics. Supporting material in the form of an exercise book was also offered to each participant (Murta et al., 2011). In PS1, the PLT was conducted by two facilitators, the researcher responsible for developing the intervention and/or psychology undergraduate or graduate (master's or $\mathrm{PhD}$ ) students. PS2 was facilitated exclusively by the developer of PLT.

Session 1 was intended for presenting the research, the participants, and ethical aspects. Data collection was done at the beginning of each session through the Dose Received Record, starting from the second session; in the last minutes of each session, when each participant was invited to respond to the Session Satisfaction Scale; immediately after the conclusion of each session, when the facilitators filled in the Field Diary; and at the end of the intervention, when the participants responded openly, in writing, about the strengths and weaknesses of the intervention (PS1) and completed sentences about the perceived impact of the intervention (PS2).

\section{Data Analysis}

Data analysis was done in three stages. In the first stage, data was analyzed according to process indicators as defined in Figure 1: recruitment, dose delivered, dose received, reach, and context (Steckler \& Linnan, 2002). In stage two, data was analyzed according to the process indicators to check if there were any viability indicators to be seen: acceptability (to what extent the participants find the intervention satisfactory and appropriate), demand, (the what extent the intervention is used by the participants and fit the school environment), implementation (to what extent the intervention is able to be executed as it was conceived, in its content and duration), practicality (to what extent the intervention is conducted with existing resources), adaptation, (how well the intervention responds to different implementation contexts), 
and integration (whether changes need to be made in the school's infrastructure for the intervention to adjust to it according Bowen et al. (2009) and Wuest et al. (2015). In the third and last stage, recommendations for adjustments in the intervention were listed for each of the indicators (Table 1). Data related to frequency and indicators of participants' satisfaction with the sessions were organized based on frequency counting. Textual data was submitted to content analysis. This technique assumes the development of following procedures: exhaustive reading of the subjects' reports, organization of the data obtained, and thematic categorization (Bardin, 1995).

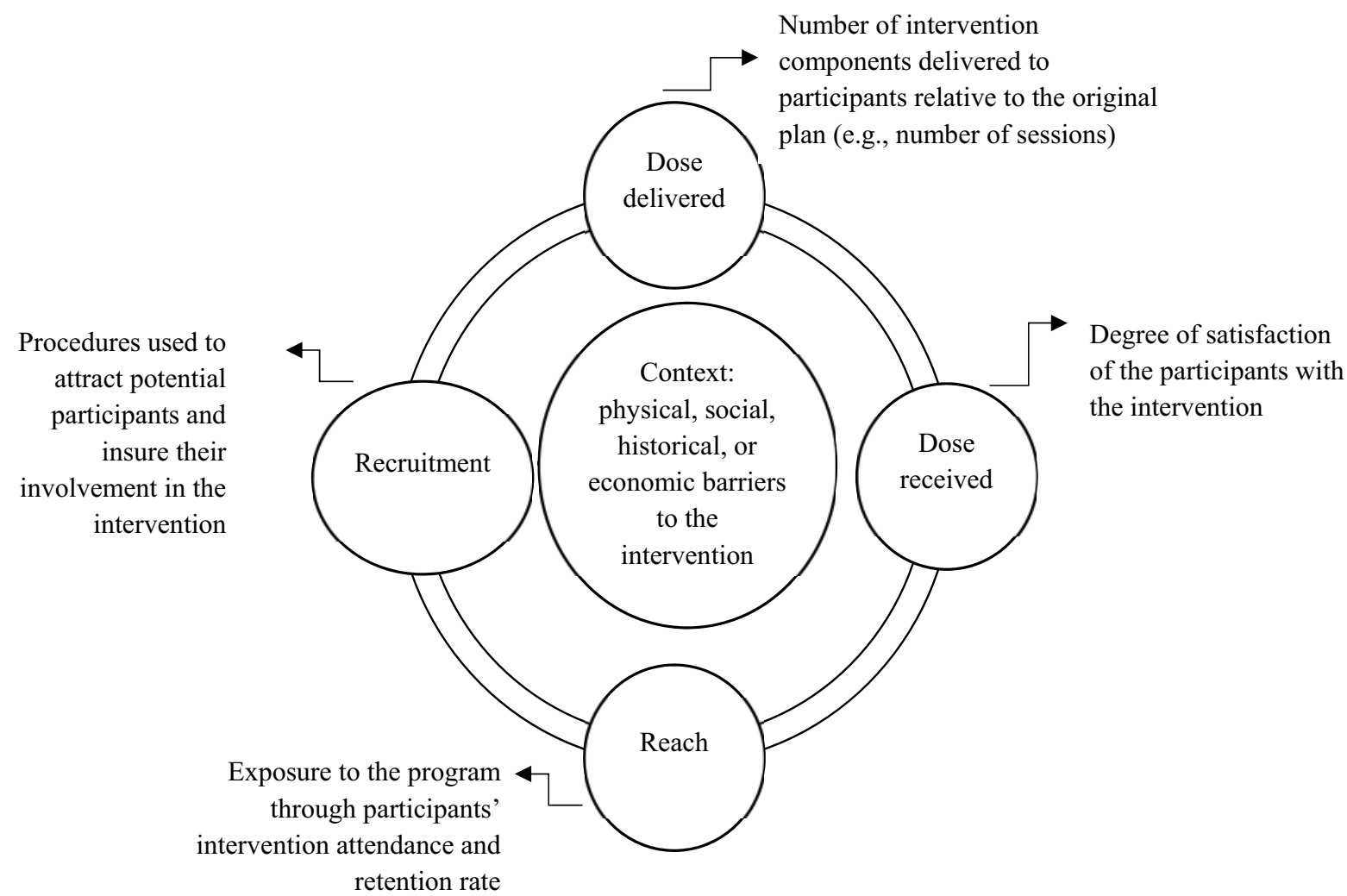

Figure 1. Intervention process monitoring indicators.

\section{Results and Discussion}

Among the process components analyzed, the context was by far the most prominent (Table 1), as monitoring of this aspect in two schools located in distinct cities and states made analysis of the contrasts and commonalities possible (Pfandenhauer et al., 2017). In both studies, the most salient context factors were: the organizational capacity of the schools; support from the schools' directors for the intervention's activities, and, especially, the integration of the program into the school curriculum. The presence of and lack of this last item was, respectively, the principle ingredient that worked in favor of PS1 and against PS2 in the successful implementation of the intervention.

Although some aspects of the context were shared between PS1 and PS2, others are specific to the particular educational environment (the school's schedule), peculiar to each educational institution (PS1: workshop format, integrated into the school curriculum; PS2: project format, extracurricular activity), or associated with external events influencing the school (teachers' strike and the FIFA World Cup). The need for adaptations, exclusions, and additions to the original intervention design was noted in the running of both studies. 
Table 1

Feasibility Evidence of Intervention Grounded on Process Indicators

Focal areas of the feasibility study

\begin{tabular}{|c|c|c|c|c|c|}
\hline $\begin{array}{l}\text { Process } \\
\text { indicators }\end{array}$ & 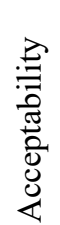 & 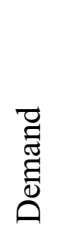 & 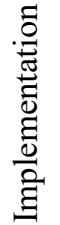 & 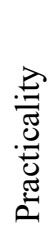 & 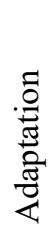 \\
\hline
\end{tabular}

Evidence

Future

recommendations

\begin{tabular}{|c|c|c|c|c|c|c|c|}
\hline Recruitment & & $\mathrm{X}$ & & $X$ & $\mathrm{X}$ & $\begin{array}{l}\text { - Difficulties with transportation/meals } \\
\text { and concurrent activities in PS2 } \\
\text { time and snacks at the school as well } \\
\text { as monitoring the students through } \\
\text { Facebook to identify adherence barriers } \\
\text { in PS2 }\end{array}$ & $\begin{array}{l}\text { at the school for } \\
\text { the intervention } \\
\text { - Test forms } \\
\text { of adolescent } \\
\text { engagement } \\
\text { in other } \\
\text { environments }\end{array}$ \\
\hline $\begin{array}{l}\text { Dose } \\
\text { delivered }\end{array}$ & & & $\mathrm{X}$ & $X$ & $X$ & $\begin{array}{l}\text { - Insertion of a session in PS2 in view } \\
\text { of the PS1 precedent (additional } \\
\text { students) } \\
\text { - Low intervention format viability, } \\
\text { covering } 40 \% \text { and } 80 \% \text { of the } \\
\text { curriculum in PS } 2 \text { and PS } 1 \text { respectively } \\
\text { - Procedures from sessions } 7,8 \text {, and } 9 \\
\text { were not tested in PS1 or PS2 }\end{array}$ & $\begin{array}{l}\text { Modify } \\
\text { intervention } \\
\text { format to shorten } \\
\text { it, in place of } \\
\text { multiple session, } \\
\text { focus on critical } \\
\text { intervention } \\
\text { components }\end{array}$ \\
\hline $\begin{array}{l}\text { Dose } \\
\text { received }\end{array}$ & $\mathrm{X}$ & $\mathrm{X}$ & & & & $\begin{array}{l}\text { - High participant satisfaction with the } \\
\text { intervention in both PS1 and PS2 } \\
\text { - Good participant involvement in } \\
\text { intervention activities in both PS1 } \\
\text { and PS2 }\end{array}$ & $\begin{array}{l}\text { - Maintain content } \\
\text { and activities } \\
\text { - Emphasize the } \\
\text { functions of the } \\
\text { peer network }\end{array}$ \\
\hline Reach & & & & $X$ & $X$ & $\begin{array}{l}\text { - Limited intervention reach in both } \\
\text { studies, being that the average student } \\
\text { participation was around twice as high } \\
\text { in PS1 compared to PS2 } \\
\text { - Low male adherence in both studies } \\
\text { - Slightly higher participant retention } \\
\text { rate in PS1 versus PS2 }\end{array}$ & $\begin{array}{l}\text { - Employ strategies } \\
\text { to increase } \\
\text { participant } \\
\text { retention } \\
\text { - Test different } \\
\text { group gender } \\
\text { compositions }\end{array}$ \\
\hline Context & & & $\mathrm{X}$ & $X$ & $\mathrm{X}$ & $\begin{array}{l}\text { - Greater intervention adherence } \\
\text { with integrated into school } \\
\text { curriculum (PS1) } \\
\text { - Lower intervention adherence with } \\
\text { done as extracurricular activity (PS2) } \\
\text { - Teachers' strike, additional activity } \\
\text { in school calendar, World Cup (PS2) } \\
\text { - Session cancelation, rescheduling of } \\
\text { meetings, early termination of PLT }\end{array}$ & $\begin{array}{l}\text { - Integrate } \\
\text { intervention } \\
\text { into the school } \\
\text { curriculum to } \\
\text { boost adherence } \\
\text { - Take school } \\
\text { calendar into } \\
\text { account when } \\
\text { scheduling the } \\
\text { intervention }\end{array}$ \\
\hline
\end{tabular}

- Lack of support for student recruitment in the PS2 interactive talk

- Few students available to participate in PS2

- Need for in-room, in-person awarenessraising after the PS2 talk

Difficulties with transportation/meals Facebook to identify adherence barriers

Insertion of a session in PS2 in view of the PS1 precedent (additiona covering $40 \%$ and $80 \%$ of the

Procedures from sessions 7, 8, and 9

High participant satisfaction with the intervention activities in both PS

Limited intervention reach in both studies, being that the average student participation was around twice as high

Low male adherence in both studies - Slightly higher participant retention

Greater intervention adherence with integrated into school in school calendar, World Cup (PS2) Session cancelation, rescheduling of
- Increase recruitment efforts (access and maintenance)

- Engage key actors at the school for ention engagement in other environments

Modify intervention format to shorten place of ession, intervention

Maintain conten Emphasize the functions of the

Employ strategies to increase participant tion Test different group gender compositions

Integrate intervention into the schoo curriculum to Take school calendar into intervention 
The recruitment procedures, detailed in the field diary indicate that the recruitment sources in both studies were similar, especially regarding the how the participants were contacted (poster in the school, Facebook banner), with the exception of the interactive talk and the inperson awareness-raising done in the classroom held only in Foz do Iguaçu. Face-to-face contact was employed to maintain continued attendance of the participants in PS1, while in PS2, beyond face-to-face contact, a closed Facebook group was created, and contact by telephone was used when necessary. In Table 1, the boost from the recruitment effort from PS1 to PS2 is clear, as much to access as maintenance. Notably in Foz de Iguaçu, few students voluntarily made themselves available to participate and, even with the increase in strategies to attract them and the addition of a session given the precedent of the entry of new students in the second Brasilia session, the number of teens recruited fell far short of what was hoped.

Anecdotal evidence from PS2 suggests engagement difficulties with the students due as much to school activities as to the non-academic ones. Educational coordination reports after the end of the program revealed aspects of the context not captured until then, such as: group heterogeneity; elevated dropout rates; that fact that students live far from school and come by bus; and the performance of short-term contracted teachers in the Simplified Selection Process (SSP). This type of contracted teacher does not promote a bond between educator and institution, nor their adherence in projects developed in the scholastic sphere. Such teachers are hourly wage-earners, at times working for more than one school and typically not getting involved in the schools' activities. Furthermore, the school accepts students without restriction, including those who have already been rejected by various other schools and, as dropout rates are high, they cannot refuse to accept them. The school director reiterated the abovementioned problems, attributing them to the school's location, which is downtown with a slum behind it, which presents adherence difficulties for afterhours program students due to lack of money for transportation and food. To overcome the challenge of conducting extracurricular activities, the director suggested looking for neighborhood schools, which tend to favor student engagement by being situated in the same neighborhood as the students, on the theory that their participation in the program would thus be more likely.

Regarding the dose delivered, there was a difference in the number of sessions offered. Twice as many sessions were held in Brasilia (8, totaling 12 hours) than in Foz do Iguaçu (4, totaling 6 hours). In Brasilia (PS1) five sessions were held according to the original plan, with content from dimensions one and two (Table 1), in the following order: session 3 (peer influence), session 5 (romantic relationships between adolescents), session 2 (teen dating violence), session 6 (healthy relationships), and session 4 (peer influence in dating). In Foz de Iguaçu (PS2), there was only one session of content on peer influence (session 3 ) related to dimension 2. In both studies, the content relative to dimension 3 , bystander intervention, although planned, was not implemented.

In Brasilia (PS1), although program limitations in the school context have been observed, whether due to the teachers' strike or because of tests and other activities on the school's schedule, the integration of intervention into the school curriculum undeniably promoted the program's achievements in several ways: dose delivered, reach, recruitment, and even a student retention rate above that of PS2 - it was able to keep at least one third of the participants up to the last session ( 6 of 18 , i.e. there were 18 participants in the first session and 6 in the last). Meanwhile, in Foz do Iguaçu (PS2), the low retention rate ( 2 of 7 , i.e. 7 participants in the first session and 2 in the last) was influenced by factors similar to PS1 (teacher strike, school schedule), higher level factors (the World Cup), and, above all, by carrying out the intervention as a sequence of extracurricular activities.

In both studies, the dose delivered was insufficient to cover the three central thematic dimensions. Two disadvantages of the intervention implementation in the form of restrictions 
from the students and/or the school, whether connected or not to the integration of the program curriculum into the school context, are worth noting: the cancellation and rescheduling of session dates and the early termination of the PS2 intervention. Broadly, the duration (90 minutes) and frequency (weekly) of the sessions were maintained in both studies, but there were differences in the duration of the intervention. However, from the point of view of exposure to the program content, the delivery of eight and four sessions respectively in PS1 and PS2 out of a total of 10 planned sessions, thus achieving $80 \%$ completeness in Brasilia and 40\% in Foz, does not translate into adherence to the planned curriculum, as the first study failed to implement the three sessions covering dimension 3, which integrated intervention critical components (7, 8, and 9), and the second study omitted six sessions $(2,4,6,7,8$, and 9$)$. That is, only $57.14 \%$ and $14.28 \%$ respectively of the sessions covering critical components were implemented in the two studies.

The findings regarding the evaluation of dose received, defined as the degree of satisfaction of the participants with the intervention, indicated that the adolescents in both studies had favorable impressions with the intervention. In PS1, the participants evaluated all eight sessions as "cool" (4) or "great" (10) or "awesome" (16), which shows an elevated level of satisfaction, notably with the subjects / themes addressed / idea of the project $(26.32 \%)$ and with having learned more (13.16\%). In PS2, information related to satisfaction was also favorable, with the three sessions evaluated as "cool" (4), "great" (6), or "awesome" (4) by virtue of the program being different / interesting (20.83\%), taking about personal experience / expression opinions (16.67\%), identifying negative aspects to improve upon (16.67\%), and making them feel at home, well, comforted (8.33\%).

Beyond this, it was possible to see through the qualitative evaluation other facets of the intervention appraised by the students over the sessions. Noteworthy among the primary reasons for the adolescents' satisfaction with the intervention were the subjects and themes addressed, practical applicability, dialogs, clarification of doubts, the amount of learning, opportunities to speak about personal experiences and express opinions, realizing things they were previously unaware of ("it was eye-opening"), identifying negative traits for improvement (timidness, shame), and help reflecting on passion and relationships, beyond revealing positive or healthy aspects of dating.

Additional information about the participants' general satisfaction with the intervention was gathered in the last session. In both pilot studies, the adolescents gave spontaneous accounts of benefits they saw as results of the intervention. In PS1, in the eighth session, an evaluation of the intervention in which the six students raised strong and weak points as well as commented freely about their experiences while participating in the project was given. Within the strong points, illuminating discussions (2), the advice dynamics (2), subjects addressed (2), creativity (1), improving relationships (2), dynamics in general (2), getting to know one's rights (1), learning the opinions of others (1), observing other couples (1), and helping other couples (1) are stressed. Among the weak points, the size/length of the instruments (3), participation (2), number of sessions (1), and low number of meetings (2) were raised. The free comments covered awareness of the theme (1), personal discovery (1), general improvement of relationships (2), new information (2), positive aspects of the workshop (5), facilitators' approaches (1), the presence of guests (1), and dynamics/activities (2).

In Foz do Iguaçu (PS2), the intervention evaluation identified the immediate effects of the project for the students by asking them about their feelings, ideas, and desires that came up over the sessions. Some excerpts that illustrate the perspective of the participants are: "My jealousy was out of control. I thought the [project's] influences in my life weren't so big but discovered that it is! Before the first meeting, I thought it was going to be boring, but I loved the project," and "This project should be everywhere in Brazil because almost no one 
knows how to deal with their partner and ends up using physical aggression".

The adolescents still admitted to challenges still to be overcome by giving themselves tasks to put in to practice starting right then, as a sort of self-prescription, ranging from taking care of their bodies and valuing self-esteem to changes in posture and behavior: "To try to have $100 \%$ sincere dialog in my dating life, lose weight ... take better care of myself, and never let my selfesteem fall! Act less on impulse!" and "Really think before taking on some attitude toward a man and woman (in love, in a romantic relationship). Be more mature and take responsibility... Make dating work!"

The benefits perceived by the students in the final evaluation can also be considered indicators of satisfaction with the intervention. In general, in Brasilia (PS1), the strengths of the program were the enlightening discussions, the subjects addressed, the advice, the improvement of relationships, and the dynamics, while the weak points were tied to number of evaluation instruments, the low attendance of some of the students, and the reduced number of sessions caused by the time restrictions of the school calendar. There was, however, a positive evaluation regarding the workshop's features (different, illuminating, interesting, and dynamic) and gaining new information. In PS2, the perceived benefits were equally promising and translated into thoughts, desires, and actions that imparted self-confidence, security, selfawareness of the amount of peer influence, and fertile reflections on romantic relationships.

In Brasilia (PS1), the average number of sessions per student was 4.17 , with the greatest number of students (18) attending session 2, which was also the only meeting attended by boys (5). The attendance of students by meeting was distributed as follows: session 1 (9 students), session 2 (18 students), session 3 (12 students), session 4 (9 students), session 5 (3 students), session 6 (13 students), session 7 (6 students), and session 8 (6 students). Session 5 , covering "Dating Violence", had low attendance due to the preparations for a music festival being held on the following day, and many of the workshop's students being engaged in it. In Foz do Iguaçu (PS2), only four meetings were held, with an average number or sessions per student of 2.28 and the following attendance record: session 1 (7 students), session 2 (5 students), session 3 (2 students), and session 4 ( 2 students). Although the coverage was greater in Brasilia compared Foz do Iguaçu, the participant retention rate was only slightly higher in PS1 (33.3\%) than in PS2 $(28.6 \%)$.

Data related to the average attendance rate of the students per session suggests, however, that the reach of the intervention was as low in Brasilia as in Foz do Iguaçu. Saunders et al. (2005) note the importance of documenting barriers to participation, indicating adherence aspects that explain, at least in part, the main personal reasons for the lack of students (difficulties with transportation, meals, and concurrent activity), especially in PS2.

In the tangle of data derived from the process and feasibility indicators (Table 1), inconsistences in the results were observed there being favorable and unfavorable evidence for the intervention's feasibility. Evidence supporting the intervention's feasibility consisted of its acceptability, with good satisfaction indicators and participant involvement, and its practicality, due to its low cost and dispensing with complex and economically onerous mate-rial and human infrastructure. The intervention revealed itself as, nonetheless, only partially viable from the point of view of demand, with reports of daily use of the intervention by the participants and being a good fit to the PS1 school environment and a poor match to that of PS2. In contrast, unfavorable feasibility evidence for the intervention was found in its implementation (local barriers impaired recruitment, intervention reach, and the offering of sessions and content as planned), adaptation (the format was incompatible with the school context, particularly in PS2), and integration (substantial changes needed to be made in the intervention's format for it to be integrated into the school routine).

Taken together, the bulk of the accumulated evidence from the findings of this study points to decisions about the intervention to be made 
concerning (1) methods to boost student retention such as integration of the intervention in the school curriculum; (2) shortening the intervention and emphasizing the critical components that embody the three main thematic dimensions, with an eye on the various structural limitations related to how the school schedule might impede the multiple-session design, minimizing its feasibility despite the intervention being integrated into normal school activities; (3) maintaining content and techniques utilized as well as the educational support material offered to the adolescents, keeping in mind the positive feedback from the students; and (4) emphasizing social and emotional support functions of peers, given the receptivity to and satisfaction with the activity about how to ask for and offer "advice" related by the adolescents (Table 1).

\section{Final Considerations}

This study examined the feasibility of a peer- and bystander approach-based intervention to prevent dating violence using two pilot studies. According to the documentation of both studies, the study was found to be viable, with good evidence for acceptability, practicality and demand, but presenting, nonetheless, some evidence of impairment in implementation, adaptation, and integration to the school environment, notably in PS2.

The findings of this study supply inputs to, on one hand, the maintenance of methods and content of the intervention and, on the other, changes to its format and integration into the school context. Evidence indicates good receptivity of the adolescents to the intervention's components and techniques, which suggests the tested intervention's compatibility with their needs. Thus, the content addressed in this intervention, integrating the dimension of dating violence and peer influence, must be maintained in future editions. In contrast, the intervention's long length added to the contextual barriers impairing the readiness of the schools to receive the complete intervention - which should cover the bystander approach dimension -and reduced the feasibility of the implementation.
Possible solutions for the problems raised in this study range from changes to the intervention to changes in the internal and external context of the school (Damschroder et al., 2009). First, the intervention could be shortened, with fewer sessions, as long as its objectives are preserved. Second, the working conditions in the school must be improved, in the sense of giving more importance to the institutional ties that allow a teacher to have work time for the planning and execution of their activities (such as in PS1), in a way that permits a link between their daily activities and pedagogical projects with transversal themes, as is the case of the present intervention. Third, educational policies that value educational objectives focused on inclusion, gender equity, and social rights are necessary for hosting this type of intervention, in that it not be considered foreign or intrusive to the school environment. It is clear that the absence of those conditions runs strongly counter to the implementation, incorporation, and sustainability of health promotion and prevention programs in organizations (May \& Finch, 2009), as is the case with schools.

The intervention's acceptability was greater with girls, having reached only a few boys. A broader understanding of the intervention's range is needed (Moore et al., 2014) to understand the low adherence of males in both studies. Anecdotal evidence from the school's coordinator in PS1 indicated embarrassment as the barrier to boys' participation, thereby explaining the fact that male students participated only in one session. These findings may signal, one the one hand, the necessity to develop materials to decrease masculine defensiveness or even the relevance of men and women co-facilitators conducting the intervention jointly. On the other hand, it is suggestive of the influence of gender composition in the reach, since the intervention in question is of mixed composition. In this case, there are alternatives such as concurrent groups of the same gender and mixed gender, or, perhaps, both arrangements in different phases of the intervention. Even with evidence suggesting greater benefits associated with male participation in groups of the same gender 
in the dating violence prevention programs (Black, Weisz, \& Jayasundara, 2012), there is no consensus in literature about an optimal gender composition (Weisz \& Black, 2009).

The main contribution of this study rests in the strength of the evidence surrounding the context as a living mesh that impacts implementation (Pfandenhauer et al., 2017). For that purpose, the double pilot test integrating the intervention's implementation documentation, which gave greater credibility to the findings, played a role. This data is aligned with that of Payne, Gottfredson, and Gottfredson (2006), who have identified the organizational capacity of the place where the intervention is applied; the presence of supportive principals in schools who back the program; and the program's integration within the regular school activities as relevant for the success of school-based prevention programs. In a similar way, Durlak and Dupree (2008), in a broad review of the effectiveness of preventive health programs, noted that the most effective programs were the best implemented ones, and, as such, received more organizational and community support. Thus, a practical implementation of these findings is necessary to construct the conditions that increase the organizational, community, and political support needed for the successful implementation of preventive programs, a task shared by managers, researchers, professionals, and potential users.

The results of this study must be interpreted in light of its limitations. Important differences in the execution of the intervention in the two cities may have been not captured by this study, even with the detailed documenting of the interventions' implementation process. While useful in the comprehension of contextual elements, especially in studies of process evaluation, the use of anecdotal evidence demands careful analysis due to the informal character of these observations and caution is necessary as it is subject to biases that can affect a rigorous evaluation of the process indicators being monitored. In this sense, the absence of systematic strategies of data collection with other informants from the school context, such as teachers and managers, constitutes the main limitation of this study.

As the evidence base for what works in dating violence prevention is limited (Edwards, \& Hinsz, 2014; Storer et al., 2016), the present study expands findings of previous studies (Amar et al., 2015; Coker et al., 2011; Coker et al., 2015; Miller et al., 2012; Palm Reed et al., 2014) by indicating contextual elements that had a significant impact on the dose delivered and on the program's reach and so reduced its feasibility. That being the case, future intervention development efforts must take in account the community's readiness prior to the implementation of preventive actions as well as develop lower cost and higher feasibility school interventions.

Future studies must keep dating violence and peer influence as core dimensions of the intervention, for which the evidence of acceptability was identified. They must still add and evaluate the bystander approach dimension that, even though planned, was not able to be implemented due to the barriers described. Future analysis of the efficacy of the currently developed intervention, after its restructuring aiming for shorter duration and execution only during school hours, will be able to investigate its impacts on the victimization and perpetration of dating violence among adolescents and Brazilian youths. Also, it is suggested that the implementation of new versions of this intervention be constructed in participative manner within the school environment, with the goal of augmenting its potential practicality, demand, adaptation, and integration.

\section{References}

Amar, A. F., Tuccinardi, N., Heislein, J., \& Simpson, S. (2015). Friends helping friends: A nonrandomized control trial of a peer-based response to dating violence. Nursing Outlook, 63, 496-503. doi.org/10.1016/j.outlook.2015.01.004

Bardin, L. (1995). Análise de conteúdo. Lisboa: Edições 70.

Barreira, K. A., Lima, M. L. C., Bigras, M., Njaine, K., \& Assis, S. G. (2014). Direcionalidade da violência física e psicológica no namoro 
entre adolescentes do Recife, Brasil. Revista Brasileira de Epidemiologia, 217-228. doi: 10.1590/1415-790X201400010017

Bartholomew, L. K., Parcel, G. S., Kok, G., Gottlieb, N. H., \& Fernández, M. E. (2011). Planning Health Promotion Programs: An Intervention Mapping Approach (3 ${ }^{\text {rd }}$ Ed.). San Francisco, CA: Jossy-Bass.

Black, B., Weisz, A. N., \& Jayasundara, D. S. (2012). Dating violence and sexual assault prevention with African American middle schoolers: Does group gender composition impact dating violence attitudes? Child \& Youth Services, 33(2), 158-173. doi/abs/10 $.1080 / 0145935 X .2012 .704788$

Boivin, S., Lavoie, F., Hébert, M., \& Gagné, M.H. (2012). Past victimizations and dating violence perpetration in adolescence: The mediating role of emotional distress and hostility. Journal of Interpersonal Violence. doi: $10.1177 / 0886260511423245$

Bonell, C., Jamal, F., Melendez-Torres, G. J., \& Cummins, S. (2015). 'Dark logic': Theorising the harmful consequences of public health interventions. Journal of Epidemiology and Community Health, 69, 95-98. doi: 10.1136/jech-2014-204671

Bowen, D. J., Kreuter, M., Spring, B., CoftaWoerpel., Linnan, L., Weiner, D., ... Fabrizio, C. (2009). How we design feasibility studies. Journal of Preventive Medicine, 36(5), 452-457. doi: 10.1016/j. amepre.2009.02.002

Branch, K. A., Richards, T. N., \& Dretsch, E. C. (2013). Reporting behavior regarding intimate partner violence an exploratory analysis of college students' response and victimization and perpetration among their friends. Journal of Interpersonal Violence, 28(18), 3386-3399. doi: $10.1177 / 0886260513504494$

Coker, A. L., Cook-Craig, P. G., Williams, C. M., Fisher, B. S., Clear, E. R., Garcia, L. S., \& Hegge, L. M. (2011). Evaluation of Green Dot: An active bystander intervention to reduce sexual violence on college campuses. Violence Against Women, 17(6), 777-796. Doi/abs/10.1177/1077801214545284

Coker, A. L., Fisher, B. S., Bush, H. M., Swan, S. C., Williams, C. M., Clear, E. R., \&
DeGue, S. (2015). Evaluation of the Green Dot Bystander intervention to reduce interpersonal violence among college students across three campuses. Violence Against Women, 21(12), 1507-1527. doi: $10.1177 / 1077801214545284$.

Damschroder, L. J., Aron, D. C., Keith, R. E., Kirsh, S. R., Alexander, J. A., \& Lowery, J. C. (2009). Fostering implementation of health services research findings into practice: A consolidated framework for advancing implementation science. Implementation Science, 4, 50. https://doi. org/10.1186/1748-5908-4-50

Durlak, J. A., \& DuPree, E. P. (2008). Implementation matters: A review of research on the influence of implementation on program outcomes and the factors affecting implementation. American Journal of Community Psychology, 41, $327-$ 350. doi: 10.1007/s10464-008-9165-0

Edwards, S. R., \& Hinsz, V. B. (2014). A metaanalysis of empirically tested school-based dating violence prevention programs. Sage Open, 1-8. doi: 10.1177/2158244014535787

Foshee, V. A., Bauman, K. E., Ennett, S. T., Suchindran, C., Benefield, T., \& Linder, G. F. (2005). Assessing the effects of the dating violence prevention program - Safe dates\| using random coefficient regression modeling. Prevention Science, 6(3), 245258. doi: 10.1007/s11121-005-0007-0

Foshee, V. A., McNaughton Reyes, H. L., Ennett, S. T., Cance, J. D., Bauman, K. E., \& Bowling, J. M. (2012). Assessing the effects of families for safe dates, a familybased teen dating abuse prevention program. Journal of Adolescent Health, 51(4), 349356. doi: 10.1016/j.jadohealth.2011.12.029

Foshee, V. A., Reyes, H. L., \& Ennett, S. T. (2010). Examination of sex and race differences in longitudinal predictors of the initiation of adolescent dating violence perpetration. Journal of Aggression, Maltreatment and Trauma, 19(5), 492-516. doi: 10.1080/10926771.2010.495032

Leen, E., Sorbring, E., Mawer, M., Holdsworth, E., Helsing, B., \& Bowen, E. (2013). Prevalence, dynamic risk factors and the efficacy of primary interventions for 
adolescent dating violence: An international review. Aggression and Violent Behavior, 18,159-174. doi: 10.1016/j.avb.2012.11.015

May, C., \& Finch, T. (2009). Implementing, embedding, and integrating practices: An outline of normalization process theory. Sociology, 43(3), 535-554. doi: $10.1177 / 0038038509103208$

McDonell, J., Ott, J., \& Mitchell, M. (2010). Predicting dating violence victimization and perpetration among middle and high school students in a rural southern community. Children and Youth Services Review, 32(10), 1458-1463. doi: 10.1016/j. childyouth.2010.07.001

Miller, E., Tancredi, D. J., McCauley, H. L., Decker, M. R., Virata, M. C. D., Anderson, H. A., ... Silverman, J. G. (2012). "Coaching Boys into Men": A cluster-randomized controlled trial of a dating violence prevention program. Journal of Adolescent Health, 51, 431-438. doi: 10.1016/j. jadohealth.2012.01.018

Mohatt, G. V., Fok, C. C. T., Henry, D., People Awakening Team, \& Allen, J. (2014). Feasibility of a community intervention for the prevention of suicide and alcohol abuse with Yup'ik Alaska Native Youth: The Elluam Tungiinun and Yupiucimta Asvairtuumallerkaa Studies. American Journal of Community Psychology, 54, 153 169. doi: 10.1007/s10464-014-9646-2

Moore, G., Audrey, S., Baker, M., Bond, L., Bonell, C., Cooper, C., ...Baird, J. (2014). Process evaluation in complex public health intervention studies: The need for guidance. Journal of Epidemiolology Community Health, 68(2), 101-102. doi: 10.1136/jech2013-202869

Murta, S. G., Borges, F. A., Ribeiro. D. C., Rocha, E. P., Menezes, J. C. L. de., \& Padro, M. de M. E. (2009). Prevenção primária em saúde na adolescência: Avaliação de um programa de habilidades de vida. Estudos de Psicologia (Natal), 14(3), 181$189 . \quad \mathrm{http} / / / \mathrm{dx}$. doi.org/10.1590/S1413294X2009000300001

Murta, S. G., Moore, R. A., Miranda, A. A. V., Cangussú, E. D. A., Santos, K. B., Bezerra, K. L. T., \& Veras, L. G. (2016). Efeitos de um programa de prevenção à violência no namoro. Psico-USF, 21(2), 381-393. http:// dx.doi.org/10.1590/1413-82712016210214

Murta, S. G., Ramos, C. E. P. L., Tavares, T. N. G., Cangussú, E. D. A., \& Costa, M. S. F. (2014). Desenvolvimento de um website para prevenção à violência no namoro, abandono de relações íntimas abusivas e apoio aos pares. Contextos Clínicos, 7(2), 118-132. doi: 10.4013/ctc.2014.72.01

Murta, S. G., Ribeiro, D. C., Rosa, I. O., Menezes, J. C. L., Ribeiro, M. R. S., Borges, O. S., ...Del Prette, Z. A. P. (2012). Programa de habilidades interpessoais e direitos sexuais e reprodutivos para adolescentes: Um relato de experiência. Psico-USF, 17(1), 21-32. http://dx.doi.org/10.1590/S141382712012000100004

Murta, S. G., Santos, B. R. P. dos, Nobre, L. A., Araújo, I. F. de, Miranda, A. A. V. M., Rodrigues, I. de O., \& Franco, C. T.P. (2013). Prevenção à violência no namoro e promoção de habilidades de vida em adolescentes. Psicologia USP, 24(2), 263268 . http://dx.doi.org/10.1590/S010365642013000200005

Murta, S. G., Santos, B. R. P., Nobre, L. de A., Oliveira, S. A., Diniz, G. R. S., Rodrigues, I. de O., ...Del Prette, Z. A. P. (2011). Diferenciando baladas de ciladas: Um guia para o empoderamento de adolescentes em relacionamentos intimos. Brasília, DF: Letras Livres.

Palm Reed, K. M., Hines, D. A., Armstrong, J. L., \& Cameron, A. Y. (2014). Experimental evaluation of a bystander prevention program for sexual assault and dating violence. Psychology of Violence. doi. org/10.1037/a0037557

Paradis, A., Hébert, M., \& Fernet, M. (2017). Dyadic dynamics in young couples reporting dating violence: An actorpartner interdependence model. Journal of Interpersonal Violence, 32(1), 130-148. doi/abs/10.1177/0886260515585536

Payne, A. A., Gottfredson, D. C., \& Gottfredson, G. D. (2006). School predictors of the intensity of implementation of schoolbased prevention programs: Results from a national study. Prevention Science, 7(2), 225-237. doi: 10.1007/s11121-006-0029-2 
Pfandenhauer, L. M., Gerhardus, A., Mozygemba, K., Lysdahl, K. B., Booth, A., Hofman, B., ...Rehfuess, E. (2017). Making sense of complexity in context and implementation: The context and implementation of complex interventions (CICI) framework. Implementation Science, 12, 21. doi.org/10.1186/s13012-017-0552-5

Priolo, S., Filho. (2017). Violência no namoro: Avaliação de um programa de prevenção (Doctoral dissertation, Universidade Federal de São Carlos, SP, Brazil).

Shorey, R. C., Zucosky, H., Brasfield, H., Febres, J., Cornelius, T. L., Sage, C., \& Stuart, G. L. (2012). Dating violence prevention programming: Directions for future interventions. Aggression and Violent Behavior, 17(4), 289-296. doi: 10.1016.j.avb.2012.03.001

Smith, C. A., Ireland, T. O., Park, A., Elwyn, L., \& Thornberry, T. P. (2011). Intergenerational continuities and discontinuities in intimate partner violence: A twogenerational prospective study. Journal of Interpersonal Violence, 26, 3720-3752. doi/ abs/10.1177/0886260511403751

Soares, J. S. F., Lopes, M. J. M., \& Njaine, K. (2013). Violência nos relacionamentos afetivo-sexuais entre adolescentes de Porto Alegre, Rio Grande do Sul, Brasil: Busca de ajuda e rede de apoio. Cadernos de Saúde Pública, 29(6), 1121-1130. doi.org/10.1590/ S0102-311X2013000600009

Steckler, A., \& Linnan, L. (2002). Process evaluation for public health interventions and research. An overview. In A. Steckler \& L. Linnan (Eds.), Process evaluation for public health interventions and research (pp. 1-21). San Francisco, CA: Jossey-Bass.
Storer, H. L., Casey, E., \& Herrenkohl, T. (2016). Efficacy of bystander programs to prevent dating abuse among youth and young adults: A review of the literature. Trauma, Violence, \& Abuse, 17(3), 256269. doi: $10.1177 / 1524838015584361$

Thompson, M. P. (2014). Risk and protective factors for sexual aggression and dating violence: Common themes and future directions. Trauma, Violence \& Abuse, 15(4), 304-309. doi: 10.1177/1524838014521025

Weisz, A. N., \& Black, B. M. (2009). Programs to reduce teen dating violence \& sexual assault-Perspectives on what works. New York: Columbia University Press.

Weisz, A. N., \& Black, B. M. (2010). Peer education and leadership in dating violence prevention: Strengths and challenges. Journal of Aggression, Maltreatment \& Trauma, 19 (6), 641-660. doi: 10.1080/10926771.2010.502089

Wuest, J., Merritt-Gray, M., Dube, N., Hodgins, M. J., Malcolm, J., Majerovich, J. A., ... Varcoe, C. (2015). The process, outcomes, and challenges of feasibility studies conducted in partnership with stakeholders: A health intervention for women survivors of intimate partner violence. Research in Nursing \& Health, 82-96. doi/10.1002/ nur.21636/

Received: $25 / 02 / 2018$

$1^{\text {st }}$ revision: $21 / 06 / 2018$

Accepted: 20/09/2018

(c))BY (C) The Author(s), 2018. Open Access. This article is distributed under the terms of the Creative Commons Attribution 4.0 International License (http://creativecommons.org/licenses/by/4.0/), which permits unrestricted use, distribution, and reproduction in any medium, provided you give appropriate credit to the original author(s) and the source, provide a link to the Creative Commons license, and indicate if changes were made. 